\title{
SELECTED RESEARCH PROBLEMS IN THE FIELD OF MEASURING STEEL USE INTENSITY IN POLISH INDUSTRY
}

\author{
Bożena GAJDZIK ${ }^{1 *}$, Marta ZAGÓRSKA ${ }^{2}$ \\ ${ }^{1}$ Silesian University of Technology, Gliwice; bozena.gajdzik@polsl.pl, ORCID: 0000-0002-0408-1691 \\ ${ }^{2}$ Polish Steel Association, Katowice; m.zagorska@hiph.org \\ * Correspondence author
}

Purpose: This publication presents selected problems in the field of measuring the intensity of steel usage in Poland. The main goal of this work is the presentation of some problems in sectoral analysis.

Design/methodology/approach: The information contained in the publication are the result of the authors' own work in the subject area of the research and may differ from information obtained from literature study, but are important for other researchers of steel use intensity because they show some problems that must be taken into account and resolved during the analysis.

Findings: At the stage of implementation of steel-usage absorption analysis, research problems arise related to the access and detail of statistical data on steel consumption by individual industry sectors in Poland, as well as input-output flows of steel products and maintained inventory levels. In order to increase the reliability of the analysis, researchers must perform a more complex test procedure regarding available data/estimated data to obtain the final structure of steel consumption. Accordingly, we discovered this to be: construction $-38.9 \%$, metal goods $-25.5 \%$, automotive $-13.5 \%$, machinery $-11 \%$, home appliances $-3.8 \%$, transport equipment $-2.4 \%$ and others $-4.9 \%$.

Practical implications: The prepared structure of steel consumption can be used to directly measure actual steel usage intensity rather than by establishing this indirectly by using statistical data alone.

Originality/value: The used methodology to describe the structure of steel consumption in Polish industry is new because there are no publications about it. Moreover, the list of research questions prepared by the authors can help other experts in analyzing steel use intensity.

Keywords: steel, steel production, steel consumption, steel use intensity.

Category of the paper: viewpoint and technical paper. 


\section{Introduction}

Steel is the basic material used in the manufacture of vehicles, equipment and machinery, structure fabrication and shipbuilding. The concept of steel use intensity belongs to a group of words with the ending "intensity" or "intensive", such as: material intensity, energy intensity, heat absorption, chemo-intensity, time-consuming, capital-intensive, labour - intensive, etc. The term "intensity" refers to tangible and intangible components of the enterprise resources or properties of the object under study (Wersty, 1993). Intensity is a form of taking over or assimilating something. Synonymous with intensity are: absorption, suction, consumption, concentration (Doroszewski, Słownik Języka Polskiego). The intensity of a material means its ease of absorption or assimilation by a given object (Encyklopedia PWN). Steel use intensity (or steel intensity of use) is the consumption of steel in the economy. In dictionaries and encyclopedias, "steel use intensity" is defined as the processing and consumption of steel by particular industrial sectors in the economy. Steel use intensity is the subject of many studies. The term "steel use intensity" is more commonly used in business (practical) than scientific use. Steel use intensity appears in the statements of managers or company owners, most often located in the steel sector or sectors purchasing steel products from steel producers. In commercial and business terms, the economy's demand for steel is referred as steel use intensity or steel intensity of use. Scientific publications use the term: "steel consumption" or "use of steel". While carrying out the literature study, an interest in the issue of steel consumption among scientific employees of technical universities and technical and scientific institutes was noted (Święchowicz et al., 1999; Rębiasz, 2003; Rębiasz et al., 2004; Gajdzik 2009, 2012). For the needs of the steel industry in Poland, the analysis of steel use intensity is carried out by the Polish Steel Association in Katowice, and steel production is part of the annual reports entitled "Polish Steel Industry" (www.hiph.org.pl). The analysis of steel use intensity is also an element of foreign industrial reports, such as: 1) World steel in figures, 2) Indirect trade in steel, published by the World Steel Association (worldsteel). The spatial scope of steel intensity analysis is wide and includes, on a macroeconomic scale, the economy of a given country, in a mezo scale: sectors/industries consuming steel, and in the microeconomic scale: individual enterprises that use or process steel in their production activities. The time range of the analysis may be retrospective (analysis of steel consumption in the past period) and/or predictive (forecasts of steel demand). The research process of steel use intensity includes:

1. Identifying and defining the research problem, as well as determining the scope of analysis and the choice of indicators for measuring steel intensity of use.

2. Analysis of availability and evaluation of the usefulness of the obtained statistical information to perform the analysis of steel use intensity. 
3. Evaluation of the value of results and determining the possibility of their application in economic policy or in enterprises (practical orientation of the research results, i.e. the answer to the question of what use will be made of the obtained information and conclusions from the implemented analysis of steel use intensity).

The purpose of this publication is to present selected problems encountered by the researcher during the implementation of steel use intensity analysis. The subjective scope of the problem concerns the analysis of steel intensity of use as exemplified by the Polish economy in the system of individual sectors of the steel consuming industries. The analysis of steel use intensity in the sectoral system of industry is not easy due to the problems related to determining the share structure of particular industry sectors in steel consumption and the flows of interbranch steel products.

This publication consists of three parts:

1. Steel use intensity: "what and how to study".

2. The scope of steel consumption measurement: "what the researcher must face".

3. Problems of measuring steel use intensity: "the usefulness of statistical information for sectoral implementation analysis of steel intensity of use".

\section{Steel intensity: "what and how study"}

The concept of steel use intensity (in Polish: stalochłonność) belongs to the group of concepts that determine the consumption of the material under study in the analyzed aspect of the research object. It is included in the concept of material use intensity, which is a measure combining the consumption or processing of materials with trends in the economy. Steel use intensity is part of the analysis of the steel market. The concepts of "material use intensity" and "steel use intensity" function in economic and business analyses. Studies on material and steel use intensity were preceded by studies on the energy use intensity of the economy.

In 1960, scientists S.H. Schurr and B.C. Netschert carried out an analysis of the energy use intensity of the American economy (Journal Challenge, 1962). A team of researchers led by these scientists analyzed energy consumption in the US economy in the years 1850-1975. The scope of the analysis was wide because it included retrospection (historical approach) and prediction (forecasts) of energy consumption and demand in the US economy. The result of their research was the report: Energy in the American Economy 1850-1975. In 1976, W. Malenbaum defined and described material use intensity (Formula 1). Material use intensity is the ratio of material consumption to the gross national product (Considine, 1991, pp. 99-115): 


$$
\frac{X i}{G N P}=\left(\frac{X i}{Y}\right) \cdot\left(\frac{Y}{G N P}\right)
$$

where:

$X_{i}$ - material intensity of use,

$Y$ - total production in sectors that indirectly consume particular materials in their production, $G N P$ - Gross National Product.

Material consumption is a component of the production function. The Total Product (TP) function represents the maximum amount of production that a company can achieve by using a given amount of inputs and materials (Formula 2) (Waśniewska, and Skrzeszewska, 2012, p. 61).

$$
T P=Q=f(K, L, M)
$$

where:

$T P, Q-$ total production, quantity,

$K$ - capital,

$L-$ labor,

$M-$ materials,

$f-$ function.

In addition to materials that are included in the classical production function, energy consumption and external services usage has been added over time. W. Welfe and A. Welfe (2004, p. 39) proposed the abbreviation CLEM for factors input: C - capital assets, L - labour, $\mathrm{E}$ - energy, $\mathrm{M}$ - materials \& services. The analysis of the production process can be conducted on a micro scale, at the level of an enterprise, mezo, i.e. a sector/sector of industry, or macro scale at the level of the economy of a given country. The spatial scope of macroeconomic analysis of steel use intensity can include local, national and international economies.

The largest global association of steel producers (Worldsteel) has proposed the following method for calculating actual steel consumption (Formula 3). Real consumption of steel is based on the SWIP index (Steel Weighted Industrial Production) (Indirect trade in steel, 2012, p. 2), in which:

$$
R S U_{t}=A S U_{t} \cdot \operatorname{normSWIP}_{t} \cdot S S U_{t}
$$

where:

$R S U_{t}$ - real steel use,

$A S U_{t}$ - apparent steel use,

normSWIP $P_{t}$ - index SWIP (average wages for changes in production in particular sectors), $S S U_{t}$. function of linear trend for results: $n o r m A S U_{t} / n o r m S W I P_{t}$, $t$ - time. 
and $A S U_{t}$ (Formula 4):

$$
A S U_{t}=S P_{t}-S E_{t}+S I_{t}
$$

where:

$$
\begin{aligned}
& S P_{t}-\text { steel production, } \\
& S E_{\mathrm{t}}-\text { steel exports, } \\
& I P_{\mathrm{t}}-\text { steel imports, } \\
& t-\text { time. }
\end{aligned}
$$

The relatively new indicator, developed in 2012 by Worldsteel TSU - True Steel Use (Indirect trade in steel, 2012, p. 2) (Formula 5), can also be used to measure the demand for steel in the economy. Herein:

$$
T S U_{t}=A S U_{t}+N I I_{t}
$$

where:

$N I I_{t}-$ net indirect import,

$A S U_{t}-$ deliveries + net direct imports,

$t$ - time.

The main objective of the new index was to gain a deeper insight into the size of steel demand in the economy by estimating the volume of flows of exports and imports of steel products contained in goods already processed by other sectors (inter-branch flows of materials).

In the studies of the Polish Steel Association in Katowice, steel use intensity is defined as apparent consumption, calculated according to Formula 4. Explicit consumption is analyzed on a national scale, whereas actual (real) consumption (Formula 3) is analyzed in relation to steel consuming sectors and business units. Real steel consumption in companies is a measure of the actual consumption of metallurgical materials for the enterprise's purposes: production and operation, construction and assembly (and others) in a given reporting period. Apparent consumption of steel products is calculated with reference to subsequent processing steps to avoid double or multiple counting of production data. Thanks to a more detailed market analysis, it is possible to estimate the unknown value of actual steel consumption in the form of an index taking into account changes in stocks held by final customers - SWIP.

On the scale of the economy, steel use intensity is calculated per unit of generated GDP or volume of sold production. The scope of such analysis can be implemented in a global system. Steel use intensity per unit of GDP is expressed in value terms at constant prices for the base year (the adopted reference year for a given reporting period). In order to avoid calculation problems, it is required to harmonize the value data to one currency. The level of steel intensity 
per capita in a given country (as the number of tonnes of steel per one inhabitant of the country) is also an important measure on the macroeconomic scale.

In addition, the inter-branch flows balance, which provides information on intermediate consumption by all sectors of the economy, can be used to measure the demand for a given material in the economy. W. Leontief's model describes the equation for the breakdown of output (Formula 6) (Plich, 2002, p. 111) with regard to structural dependencies:

$$
X_{i}=\sum_{j=1}^{n} x_{i j}+Y_{i}
$$

where:

$X_{i}$ - quantity (volume) of total production in $i$-branch,

$x_{i j}$ - a part of production $i$-branch for production of products in $j$-branch,

$Y_{i}$ - final materials use in $i$-branch.

Steel inter-branch flows should be included in the steel intensity analysis so as to determine the actual level of steel consumption for a given manufacturing sector. The scope of the analysis of steel consumption by industry sector is very wide. On the basis of input-output data, it is possible to examine the structure and changes in consumption of production of a given branch, to assess the effectiveness of the use of particular types of inputs (material intensity), to examine the size of the connection of individual sectors with foreign countries (based on the import intensity ratio) and forecast the value of demand for products of a given industry (Czyżewski, and Grzelak, 2012).

\section{The scope of steel consumption measurement: "what the researcher must face"}

The issues of the scope of measuring steel use intensity include a wide set of research questions. The answers to individual questions can be given by: scientists, researchers, steel market experts and managers in steel companies. The basic research questions are summarized in Table 1. 


\section{Table 1.}

\section{Basic questions about measuring steel intensity of use}

\begin{tabular}{|c|c|}
\hline $\begin{array}{l}\text { The scope of } \\
\text { research }\end{array}$ & $\begin{array}{l}\text { - How to define steel and steel products (steel products categorization)? } \\
\text { - What is the steel productivity (steel productivity is calculated as the product of the } \\
\text { amount of steel products consumed by the weighted sum of the number of steel } \\
\text { products consumed, where the weights are determined on the basis of the price } \\
\text { relationship of individual types of steel products within the local market (Kosieradzka, } \\
2012, \text { p. 70, prepared on basic material productivity)? } \\
\text { - What is the spatial scope of research: enterprise, industry sector/industry, } \\
\text { regional/national/international economy? } \\
\text { - What level of detail is needed when assessing steel intensity? } \\
\text { Which measurement of steel use intensity should be applied in the assessment/ } \\
\text { analysis? } \\
\text { - What time range of the analysis should be used - the length of the time horizon of the } \\
\text { research (month, quarter, year)? } \\
\text { What kind of analysis to perform: historical (past years) or forward-looking (future } \\
\text { years)? } \\
\text { What will be the volume and frequency of tests (a single research package, periodic } \\
\text { tests, systematic tests, permanent tests)? } \\
\text { Do comparative analysis, e.g. comparison of steel use intensity in individual } \\
\text { enterprises, industrial sectors or in individual economies of countries? }\end{array}$ \\
\hline $\begin{array}{l}\text { Steel market } \\
\text { (steel producers } \\
\text { and users) }\end{array}$ & $\begin{array}{l}\text { What is the volume (quantity) of steel production (valuable and quantitative in tonnes, } \\
\text { - Wnits, etc.)? } \\
\text { - What is the market price of steel/individual steel products? } \\
\text { - What are the trends within the steel market and what external factors affect the volume } \\
\text { - What is the structure of the market: } \\
\text { - by industry (steel producers), } \\
\text { - by steel recipients/consumers (sectors of the steel processing and consuming } \\
\text { - industry), } \\
\text { - in geographical terms (location of steel producers and consumers)? } \\
\text { - What is the share of individual industry sectors in steel consumption (consumption)? } \\
\text { - What is the volume of steel exports and imports? } \\
\text { - What is the share of individual industry sectors/steel producers/consumers in the } \\
\text { - What is the level of stocks of steel products held by enterprises? } \\
\text { - What will be the future trends within the steel market (e.g. technological trends, } \\
\text { climate package - environmental protection)? } \\
\text { What will be the steel demand - the absorptive power of the steel users market } \\
\text { (specific sectors of the industry consuming steel/producers: cars, equipment and } \\
\text { machinery, building structures, ships and other means of transport)? }\end{array}$ \\
\hline $\begin{array}{l}\text { Macroeconomic } \\
\text { conditions }\end{array}$ & $\begin{array}{l}\text { - What is the condition of the economy? } \\
\text { - What is the GDP level? } \\
\text { - What is the volume of sold production? } \\
\text { - How many inhabitants does the region/country/economic block have? } \\
\text { Other: What government regulations regarding steel trade? }\end{array}$ \\
\hline $\begin{array}{l}\text { Information } \\
\text { availability }\end{array}$ & $\begin{array}{l}\text { - What information is really necessary to perform steel use intensity analysis (is the } \\
\text { information obtained useful)? } \\
\text { - What is the access to information sources like (e.g. published by statistical units - mass } \\
\text { statistics, associations of steel producers, metallurgical organizations - steel industry } \\
\text { statistics)? }\end{array}$ \\
\hline $\begin{array}{l}\text { Researcher's } \\
\text { experience }\end{array}$ & $\begin{array}{l}\text { - What is the level of knowledge of the steel industry by the researcher? } \\
\text { - What alternative solutions can be used to solve selected problems of measuring steel } \\
\text { use intensity (e.g. data estimation)? }\end{array}$ \\
\hline $\begin{array}{l}\text { Utility of } \\
\text { research }\end{array}$ & $\begin{array}{l}\text { - What is the value of the results obtained for the functioning of enterprises, industrial } \\
\text { development and economy (e.g. usefulness of research in the process of making } \\
\text { strategic decisions for enterprises or for assessing the effects of managers' decisions, } \\
\text { including operational decisions taken in an enterprise)? }\end{array}$ \\
\hline
\end{tabular}

Source: B. Gajdzik - own study. 
The list of questions presented in Table 1 is not complete, but it gives an idea of the type of questions that should be asked by every steel market researcher and contractor of steel absorption analysis. Searching for answers to further formulated questions during the implementation of the steel use intensity analysis is conditioned by many factors depending on the researcher himself, e.g. the researcher's experience, the ability to solve research problems, knowledge of computer programs, as well as independent of the research implementer, e.g. the availability of statistical information.

\section{Problems of measuring steel intensity of use: "The usefulness of statistical information for sectoral implementation analysis of steel use intensity"}

The problems of measuring steel consumption in the system of industrial sectors using steel in production processes are presented utilizing the example of Poland's steel industry. The source of information was statistical data within the framework of access to mass information - statistical studies of the Central Statistical Office (GUS) (www.stat.gov.pl). In order to perform the analysis of steel use intensity by sector, the balance of inter-branch flows in Poland was used (statistical data) - tables entitled Balance of Inter-branch Flows and the structure of use of products from the sector "Production of Metals" - (Basic metals NACE 24). The calculations also take into account the use of products from domestic production and imports. This information was employed to identify the key industry sectors steel consumers. At the stage of detailing the key sectors, data on stocks (reduction of steel intensity of use) were also taken into account, and steel consumption was adjusted by the volume (value) of exports (these data are not included in the calculation of explicit consumption). In addition, the calculations have also to be adjusted for own consumption (subsequent stages of metal processing), as well as scrap recovery and trading activities. Summary - Table 2 - example statistical data included in the analysis.

Table 2.

Data for the analysis of sectoral steel intensity in Poland in 2015

\begin{tabular}{|l|c|c|c|c|c|c|c|}
\hline \multirow{3}{*}{ Year } & \multicolumn{6}{|c|}{ Total consumption [\%] } \\
\cline { 2 - 8 } & \multicolumn{3}{|c|}{ Final consumption } & \multicolumn{4}{c|}{ Intermediate consumption } \\
\cline { 2 - 8 } & Households & Stocks & Exports & Own & $\begin{array}{c}\text { Scrap } \\
\text { recovery }\end{array}$ & Trade & $\begin{array}{c}\text { Other } \\
\text { sectors }\end{array}$ \\
\hline 2015 & 0.3 & 0.7 & 35.5 & 17.9 & 2.3 & 1.0 & 42.3 \\
\hline
\end{tabular}

Source: M. Zagórska, data from data from Central Statistical Office (in Polish: GUS), "Production of Metals".

The remaining value was analyzed in terms of the volume of direct consumption in the various steel-consuming sectors. The largest share (about 39\% in 2015) was recorded for the sector: Production of metal products (NACE 25), which, however, is largely associated with 
the processing of steel products (most - 30\% of all product flows to this branch are metals). Therefore, it is possible to calculate the value of indirect consumption of metals processed by the metal goods sector in the country in the form of metal products delivered to other sectors, excluding the same categories as in the case of metals, i.e. export sales, own consumption or trade. After separating product flows, the metal goods sector still remained the largest consuming branch, but its share decreased to $23 \%$. The automotive industry was ranked in the second position with a share of $19 \%$, and the construction sector was ranked third with a share of $14.3 \%$, together with all branches whose basic activity does not consist in the manufacturing of goods containing metals, but uses these metals to create infrastructure, i.e. the power industry, water supply and services including: transport, warehousing and property management. Other sectors with a significant share include: manufacturing of machinery and equipment, manufacturing of electrical equipment, manufacturing of electronic products and manufacturing of other transport equipment. The results of the sectoral consumption structure of metals are presented in Table 3.

Table 3.

Consumption of metal products in Poland

\begin{tabular}{|c|c|c|c|}
\hline \multirow{2}{*}{ Sectors of industry } & \multicolumn{2}{|c|}{ Year } & $\mathbf{2 0 1 5}$ \\
\cline { 2 - 4 } & $\mathbf{2 0 0 5}$ & $\mathbf{2 0 1 0}$ & $22.3 \%$ \\
\hline Metal goods & $21.3 \%$ & $20.5 \%$ & $19.0 \%$ \\
\hline Automotive & $13.0 \%$ & $19.2 \%$ & $17.8 \%$ \\
\hline Construction & $21.6 \%$ & $19.7 \%$ & $13.2 \%$ \\
\hline Machinery & $20.9 \%$ & $13.7 \%$ & $13.0 \%$ \\
\hline Electrical equipment & $11.6 \%$ & $12.6 \%$ & $3.4 \%$ \\
\hline Electronics & $1.2 \%$ & $4.3 \%$ & $3.4 \%$ \\
\hline Other transport & $4.1 \%$ & $2.8 \%$ & $7.2 \%$ \\
\hline Others & $6.4 \%$ & $7.2 \%$ & \\
\hline
\end{tabular}

Source: M. Zagórska, data from Central Statistical Office (in Polish: GUS): www.stat.gove.pl/ consumption of metal products.

The problems that arise during the analysis of steel intensity for particular sectors of the industry in Poland that use steel are:

- lack of available data by product breakdown in the statistics,

- the need to analyze the whole metals branch (steel products, casting products, non-ferrous metal products),

- the need to perform the analysis only on the basis of valuable data (difficulty in translating it into apparent consumption due to price differences),

- low frequency of data publication (every 5 years),

- significant delay in data publication $(+3.5$ years $)$.

For comparison of the obtained calculations of steel intensity in the sectoral system, the sectoral consumption of steel products should also be analyzed in terms of quantity and value. For the purpose of quantitative analysis, more detailed CSO data should be used and can be drawn from the study entitled "Materials management" (CSO). It should be possible to separate out particular steel product ranges from this study. In case of the lack or aggregation 
of data on part of the assortments, it is necessary to estimate the share of particular sectors in steel consumption.

Another problem appeared at the stage of analysis of the classification of steel consuming sectors according to NACE (NACE Classification Scheme 2007, Central Statistical Office). In dealing with the data as arranged, researchers must make decisions to separate or merge individual divisions to increase the accuracy of apparent steel consumption analysis. The Polish PKD classification [https://stat.gov.pl/Klasyfikacje] is based on the nomenclature of activities used in the EU. Here, NACE was compared with the classification of steel consuming sectors used in the EU steel association - Eurofer (Economic and steel market outlook 2019-2020, p. 23, online: [Economic and steel market outlook 2019-2020" Eurofer www.eurofer.org, http://www.eurofer.org/Issues\%26Positions/Economic\%20Development\% 20\%26\%20Steel\% 20Market/Economic\%20Development\%20\%26\%20Steel\%20Market.itpl]. As a result, verified key steel consuming sectors were obtained.

At this stage, the structure of steel consumption of individual steel users was recalculated (taking into account the product mix). The reliability of the analysis was also enhanced by comparison of the results obtained on the basis of statistical data (mass information provided from enterprises to the Central Statistical Office in reporting statements) with industry data at the national level - HIPH information. However, the total consumption of steel products measured by the end-user identification method is incomplete because the volumes declared by steel users are lower than the study of steel consumption at the level of the entire economy that was obtained by using the formula:

apparent steel consumption $=$ finished steel production - steel exports + steel imports.

Data gained from "CSO studies - a summary: material management" covers approx. $60 \%$ of the data on domestic apparent consumption developed by HIPH (Table 4).

This discrepancy in data may be due to:

- the incomplete congregation of enterprises,

- lack of data concerning usage in some sectors of the economy (e.g. services),

- purchase of materials by companies for use in external services, especially construction, and the use of processed products in their production.

Table 4.

Materials management and industry data for steel consumption in Poland [tonnes]

\begin{tabular}{|c|c|c|c|}
\hline Year & $\begin{array}{c}\text { Consumption in enterprises } \\
\text { (source: GUS) }\end{array}$ & $\begin{array}{c}\text { Supply and trade } \\
\text { (source: HIPH) }\end{array}$ & $\begin{array}{c}\text { Difference } \\
\text { (Data from source 1 minus } \\
\text { data from source 2) }\end{array}$ \\
\hline 2005 & 4691000 & 7944000 & -3253000 \\
\hline 2010 & 6320000 & 10086000 & -3766000 \\
\hline 2015 & 7459000 & 12432000 & -4973000 \\
\hline
\end{tabular}

Source: M. Zagórska, data from data from Central Statistical Office (in Polish: GUS): „Gospodarka materiałowa" Materials management [Gospodarka materiałowa 2004-2017", https://stat.gov.pl/obszarytematyczne/przemysl-budownictwo-srodki-trwale] and HIPH - Polish Steel Association in Katowice. 
The divergence of statistical data published by statistical units and industry data necessitate the need to re-verify the structure of steel consumer sectors. To obtain a $100 \%$ share of all market participants - steel recipients were based on expert knowledge. As a result, a detailed structure of domestic industry sectors in terms of steel consumption was obtained (for a given calendar year) (Figure 1). The structure of steel-consuming (steel-processing) industries can also be assessed on the basis of weights expressing the importance of individual industry sectors for the development of the economy.

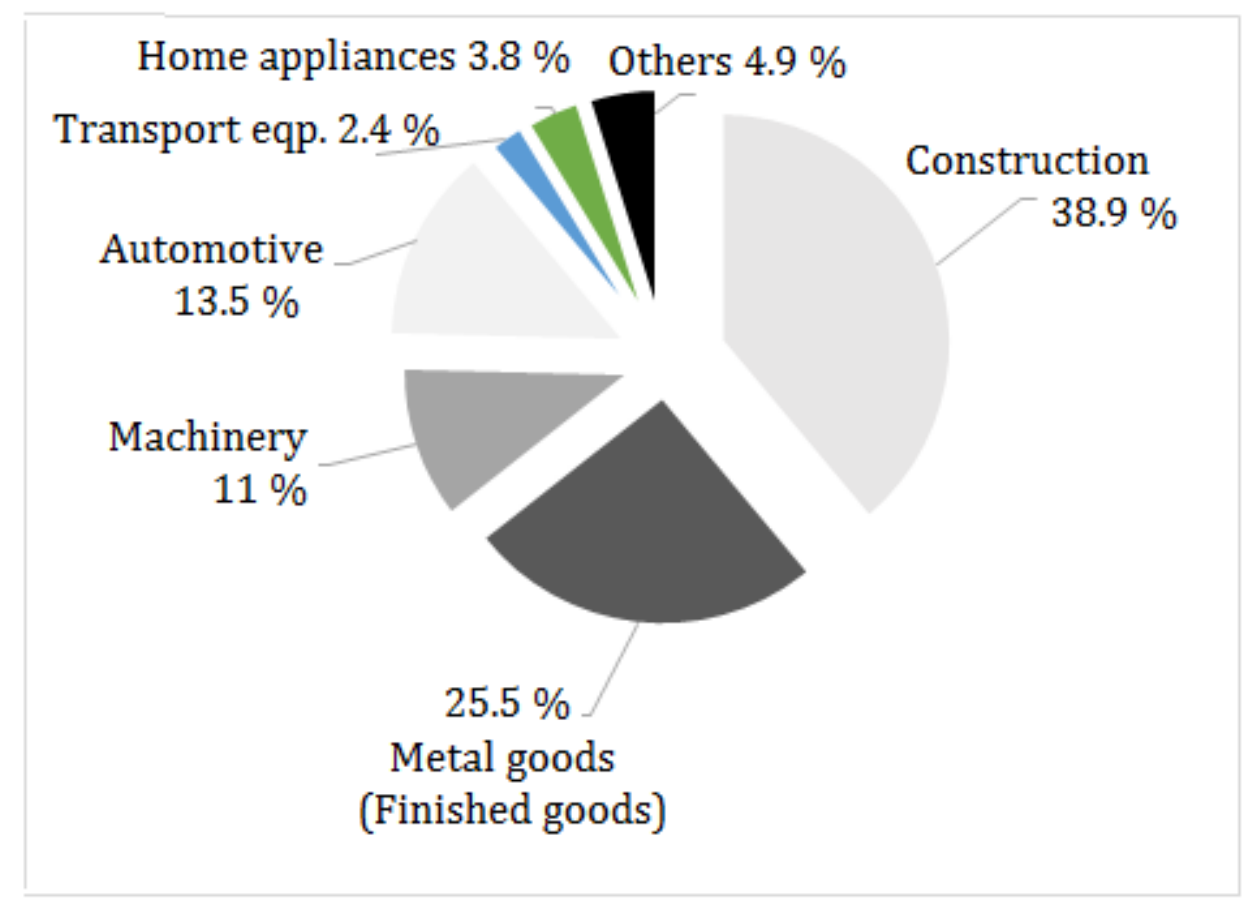

Figure 1. Final form of the structure of steel consumers in Poland. Source: own analyses.

\section{Conclusion}

At the stage of implementation of the steel absorption analysis in the sectoral system, research problems arise related to the access and detail of statistical data on steel consumption by individual industry sectors in Poland, as well as input-output flows of steel products and maintained inventory levels. A detailed scope of problems is presented in this publication. In order to increase the reliability of the analysis, the steel absorber researcher must perform a more complex test procedure. At the stage of determining the scope of the analysis, the researcher should obtain the answers to the questions listed in Table 1 and choose steel use intensity measurement measures ranging from general measures for steel consumption in economic terms per GDP or per capita, to indicators taking into account steel import and export and the use of steel in individual sectoral industry, including inter-branch flows, and even inventory levels and product mix structure. Using secondary information sources, the researcher 
must perform a reliable assessment of the usefulness of statistical information for measuring steel intensity of use. Analysis of steel use intensity in the sectoral system of industry is not easy, there are problems associated with determining the share structure of steel sectors of the industry consuming steel based on statistical data. The structure of key industry segments in Poland presented in the paper - steel consumers (Table 3, Figure 1) will be the subject of further studies on the steel use intensity of industry in Poland. The structure proposed in the publication will be the basis for the analysis of steel intensity of use in the sectoral system over a period of several years (historical approach) and development of forecasts of steel demand for the coming years in Poland.

\section{References}

1. Bilans Przepływów Międzygałęziowych w 2005, 2010 i 2015 roku. Warszawa: GUS, https://stat.gov.pl/obszary-tematyczne/rachunki-narodowe/roczne-rachunki-narodowe/ bilans-przeplywow-miedzygaleziowych-w-biezacych-cenach-bazowych-w-2015roku, 7,3.html.

2. Czyżewski, A., and Grzelak, A. (2012). Możliwości wykorzystania statystyki bilansów przepływów międzygałęziowych. Przegląd Statystyczny, 1, 173-190.

3. Doroszewski, W. Stownik języka polskiego, https://sjp.pwn.pl/doroszewski/chlonnosc; 5416700.html.

4. Economic and steel market outlook 2019-2020. www.eurofer.org, http://www.eurofer.org/ Issues \%26Positions/Economic\%20Development\%20\%26\%20Stee1\%20Market/Economic \%20Development\%20\%26\%20Steel\%20Market.itpl , 23.

5. Considine, T.J. (1991). Economic and Technological Determinants of the Material Intensity of Use. Land Economics, 67(1), 99-115. Available online https://www.jstor.org/stable/ 3146489.

6. Encyklopedia PWN. Hasło: materiałochłonność, https://encyklopedia.pwn.p1/haslo/ materialochlonnosc;3938584.html.

7. Gajdzik, B. (2009). Przedsiębiorstwo hutnicze po restrukturyzacji. Gliwice: Wydawnictwo Politechniki Śląskiej.

8. Gajdzik, B. (2012). Przedsiębiorstwo hutnicze po restrukturyzacji. Dynamika zmian w krajowym sektorze hutniczym w latach 1992-2010. Gliwice: Wydawnictwo Politechniki Śląskiej.

9. Gospodarka materiałowa 2004-2017. Warszawa: GUS, https://stat.gov.pl/obszarytematyczne/przemysl-budownictwo-srodki-trwale.

10. Indirect trade in steel. Definitions, methodology and applications (April 2012). World Steel Association (worldsteel). Available online https://www.worldsteel.org. 
11. Kosieradzka, A. (2012). Zarządzanie produktywnościa w przedsiębiorstwie. Warszawa: C.H. Beck, 70.

12. Plich, M. (2002). Budowa i zastosowanie wielosektorowych modeli ekonomicznoekologicznych. Łódź: Uniwersytet Łódzki, 111.

13. Polski przemyst stalowy, raporty roczne. Katowice : Hutnicza Izba Przemysłowo-Handlowa (HIPH), www.hiph.org.pl.

14. Rębiasz, B. (2003). Analiza stalochłonności PKB w Polsce w latach 1992-2001. Gospodarka Materiatowa i Logistyka, 1, 15-18.

15. Rębiasz, B., Garbarz, B., Szulc, W. (2004). Wpływ dynamiki i struktury rozwoju gospodarczego Polski na krajowe zużycie stalowych wyrobów hutniczych. HutnikWiadomości Hutnicze, 71(9), 454-458.

16. Schemat Klasyfikacji PKD (2007). Warszawa: GUS, https://stat.gov.pl/Klasyfikacje.

17. Schurr, S.H., and Netschert, B.C. et al. (1962). Energy in the American Economy 18501975. Journal Challenge, 10(9), Taylor\&Franics, https://www.tandfonline.com/doi/abs/ 10.1080/05775132.1962.11469448? journalCode=mcha20.

18. Święchowicz, M., Macioł, A., Rębiasz, B., Stawowy, A. (1999). Prognozowanie produkcji stali na podstawie analizy dynamiki rozwoju sektorów stalochłonnych przy użyciu metod inżynierii wiedzy. In: R. Knosala (ed.), Komputerowo zintegrowane zarzadzanie. II konferencja: Zakopane, 11-13 stycznia 1999. Warszawa: WNT, 421-426.

19. Waśniewska, A., and Skrzeszewska, K. (2012). Ekonomia menedzerska. Podstawy teoretyczne z zdaniami. Gdynia: Akademia Morska w Gdyni, 61.

20. Welfe, W., and Welfe A. (2004). Ekonometria stosowana. Warszawa: PWE, 39.

21. Wersty, B. (ed.) (1993). Analiza ekonomiczna w przedsiębiorstwie. Wrocław: Wydawnictwo Akademii Ekonomicznej.

22. Zagórska M. Modele prognozowania produkcji wyrobów do określania kierunków rozwoju rynku stalowego (praca doktorska w trakcie realizacji na Wydziale Inżynierii Materiałowej Politechniki Śląskiej (promotor B. Gajdzik). 